Research Article

\title{
COMPARATIVE STUDY ON THE ADOPTION OF IMPROVED BEEKEEPING TECHNOLOGY FOR POVERTY ALLEVIATION
}

\author{
S. J. Bhusal ${ }^{1}$ and R. B. Thapa ${ }^{2}$ \\ ${ }^{1}$ Regional Agriculture Research Station, Tarahara, Sunsari, Nepal \\ ${ }^{2}$ Institute of Agriculture and Animal Sciences, Rampur, Chitwan, Nepal
}

\begin{abstract}
Adoption of improved beekeeping practices was compared between the mobilized (Pragatinagar VDC) and non-mobilized (Makar VDC) farmers' groups ( $\mathrm{n}=14$ in each VDC) of Nawalparasi district using semistructured questionnaire survey after introducing improved beekeeping practices during 2002/2003. Majority of the households $(82.4 \%$ ) from mobilized group practiced beekeeping enterprise of which $80.6 \%$ followed improved practices with adoption index of $77.44 \%$ while from non-mobilized group only $56.0 \%$ adopted beekeeping enterprise and $68.4 \%$ followed improved beekeeping practices only with the adoption index of $58.73 \%$. Annual honey yield per colony was significantly higher among mobilized farmers' group $(25.6 \mathrm{~kg}$ earning NRs 25,657.14) than that of non-mobilized farmers' group (15.6 kg earning NRs 10,364.29). Women involvement was low in enterprise development and adoption in both VDCs $(31.8 \%$ and $50.0 \%$ in mobilized VDC; and $35.7 \%$ and $48.2 \%$ in non-mobilized VDC). Therefore, transfer of improved technology to subsistence farmers emphasizing women through social mobilization could help generate income and alleviate poverty.
\end{abstract}

Key words: Beekeeping, social mobilization, adoption index, gender, income

\section{INTRODUCTION}

In Nepal, modern beekeeping was initiated 15 years ago (Entomology Division, 1998; Shivakoti and Bista, 2000) with the introduction of moveable frame hives to rear Apis cerana F. (Kafle, 1992). Beekeeping with improved and imported crossbreed honeybee, Apis mellifera L. started since 1993-1995 (Entomology Division, 1999; Thapa and Pokhrel, 2001). However, the average annual honey yield in the country is only $4.15 \mathrm{~kg}$ per colony (HMG/N, 2002).

Since food security is not possible without income security (Koirala and Thapa, 1997), honey production through beekeeping could be a useful avenue for improving rural economy (Baptist and Punchihewa, 1983). Nepal Agricultural Perspective Plan (APP) has recognized beekeeping as high value income generating enterprise (APROSC and JMA, 1995). Poor, marginal and even landless farmers can benefit from beekeeping to support their livelihoods as it can be started even with limited resources giving income and supplying nutrition to them (ICIMOD, 1999).

Nepal is rich in ecological resources and is one of the ideal places for beekeeping (Shrestha and Verma, 1992) but necessitates scientific technology for low-investment profile (Verma et al., 2000). The improved technology is lacking in most rural areas (Shrestha, 2000). Extension work is, therefore, crucial for the successful promotion of beekeeping through the transfer of skills and knowledge from specialists (Saville, 2000) which should be labour intensive as a part of agriculture (Pant, 1983).

Community participation is a mean to increase efficiency aiming at initiating mobilization for collective action, empowerment and institution building (Pretty, 1996). Social mobilization can play an important role to start improved beekeeping enterprise in the rural community assisting with resources, structure and capabilities to solve problems for higher productivity and marketing. Training has enhanced adoption of beekeeping with greater harvesting (Srivastava and Tripathi, 1983) and adoption of $A$. mellifera and mobilization has increased honey production compared to $A$. cerana in Pakistan (Muzaffar, 2000). Therefore, improved beekeeping enterprise with high yielding race, $A$. mellifera and its adoption through training and mobilization of the rural poor and disadvantaged people can generate income, solve unemployment problem and help alleviate poverty thereby preventing migration as well. This study was focused to assess adoption of improved technology and compare the adoption rate and income through beekeeping at farmers' level. 


\section{MATERIALS AND METHODS}

\section{Study site}

The comparative adoption study of improved beekeeping technology was conducted in Nawalparasi district where the enterprise is being popular occupation among farmers for income generation and its technology is in the adaptive phase for honey production. Modern beekeeping technology was started since 1996 in the district, however, it was practiced traditionally long before with indigenous honeybee (A. cerana $\mathrm{F}$.) colonies in wall and log hives (DADO, Nawalparasi, 2001).

Two VDCs namely Pragatinagar (mobilized) and Makar (non-mobilized) were selected for the study with the help of Participatory District Development Program (PDDP), District Agriculture Development Office (DADO) and Micro-enterprise Development Program (MEDEP), Nawalparasi.

\section{Key informant survey}

Four progressive farmers in each VDC were interviewed with unstructured interview schedules focusing relevant topics to prepare a comprehensive list of households and related problems in adopting beekeeping as an enterprise.

\section{Selection of improved beekeeping practices}

The improved practices selected after reviewing relevant references and personal communication with the advisory committee and other apiculturists were: 1 . Beekeeping occupation and type of hive products; 2 . Honeybee races and management technology; 3. Seasonal management and routine inspection; 4. Colony union; 5 . Colony division; 6. Artificial queen rearing; 7. Use of comb foundation; 8. Artificial feeding; 9. Foraging management and pollination; 10. Swarming and absconding control; 11. Robbing control; 12. Honeybee pest (mite) and predator management; 13. Disease management; and 14. Honey harvesting and processing

\section{Improved technology introduction}

Improved technology was introduced among the participating farmers through group approach organizing them to visit nearby successful beekeeping enterprises and interaction was carried out for sharing knowledge and skills among themselves. The participating farmers were followed up time to time and finally refresher training was imparted to them for adopting the beekeeping as an enterprise with improved technology.

\section{Survey questionnaire and pre-testing}

A survey questionnaire was prepared reviewing relevant references and personal communications with advisors and other apiculturists, and pre-testing was carried out with five household heads in Devchuli VDC (in the vicinity of research site having socio-economic and geographical conditions as that of study locale) to determine the applicability of the data collection instrument in the actual field situation. Final semi-structure questionnaire was developed after incorporating necessary corrections.

\section{Farmer selection and data collection}

All the households adopting beekeeping enterprises were selected to constitute final sample size of 14 in each VDC for obtaining greater degree of representation and thus decreasing the probable sampling error. Then, the semi-structured questionnaire was administered face to face to collect all the information from the selected household heads with the methods of cross-reference in order to validate the trustworthiness of the data. Both qualitative and quantitative research methods were applied to collect information and presentation of results.

\section{Sources of information}

Required information was obtained from both the primary and secondary sources. The primary information was collected through household survey, which was supplemented and verified by the information collected through the group meeting and discussion. The secondary information was obtained by gleaning through publications from various institutions and agencies.

\section{Construction of scale}

The scale for the measurement of the extent of adoption of selected improved beekeeping practices by 
the beekeeping farmers was prepared by assigning 1 to 5 scales to each practice, i.e. ' 1 ' to the least and ' 5 ' to the most important (Dangol, 1979) thus assigning different weights of numerical value on the basis of relative importance in the adoption of selected improved practices at farmers' level. The constructed scale was then administered to 10 judges (apiculturists) to rate these selected practices on the given five point scale and mean scores for each practice were calculated, which was multiplied by a common figure ' 5 ' for the convenience of calculation (Table 1). Then another format was administered to those 10 judges requesting them to distribute total scores under sub-headings of each practice based on the importance.

\section{Data analysis and adoption testing}

The collected data were managed and analyzed using computer software- Ms Excel, SPSS and MSTATC. Finally, the households adopting each practice and the extent of technology adoption in the selected VDC were calculated using following formulae (modified after Dangol, 1979 and Devkota, 1987).

$$
\begin{aligned}
& \text { Adoption of technology }=\frac{\text { Number of households adopting technology }}{\text { Total Number of respondent households }} \times 100 \% \\
& \text { Extent of adoption }= \\
& \text { Adoption Index (A.I.) }=\frac{\text { Total adddoption score obtained by an individual }}{\text { Maximum score one can obtain }} \times 100 \% \\
& \times 100 \%
\end{aligned}
$$

\section{RESULTS AND DISCUSSION}

\section{Study area}

Nawalparasi is one of the six districts of Lumbini zone covering Terai, Inner Terai and hilly areas. Geographically, it lies between $26^{\circ} 12^{\prime}-27^{\circ} 47^{\prime}$ north latitude and $86^{\circ} 36^{\prime}-84^{\circ} 35^{\prime}$ east longitude with altitude ranging from 100 to 1936 meters from the mean sea level (DADO, Nawalparasi, 2001).

There were 1450 honeybee colonies in the district, of which 400, 250 and 800 were traditional, improved indigenous (A. cerana), and improved exotic (A. mellifera) colonies with honey productivity of $4 \mathrm{~kg}, 8 \mathrm{~kg}$ and 18 $\mathrm{kg}$ per colony per annum producing total of $1,600 \mathrm{~kg}, 2,000 \mathrm{~kg}$ and $14,400 \mathrm{~kg}$ honey, respectively, in the fiscal year 2000/2001 (DADO, Nawalparasi, 2001). The yield of honey in Nawalparasi from traditional beekeeping was less than the national average honey yield of $4.15 \mathrm{~kg}$ per colony per annum (HMG/N, 2002). However, modern beekeeping exceeds the national average honey productivity.

There were three beekeeping resource centers namely, Sagar at Gaidakot, Daunnedevi at Dumkibas and Bhusal Beekeeping Resource Center at Dumkibas in Nawalparasi district alone out of 17 centers in the country (HMG/N, 2002). The pocket areas for beekeeping in Nawalparasi are Agyauli, Devchuli, Pragatinagar, Dibyapuri, Mukundapur, Gaidakot, Dumkibas, Makar and Sunawal (Shakya, 2003).

Both the VDCs selected for the study are situated across the Mahendra Highway. Pragatinagar VDC is surrounded by Dibyapuri VDC in the east, Shivamandir and Pithauli VDC in the west, Devchuli VDC in the north and India in the south. Similarly, Makar VDC is surrounded by Dumkibas VDC in the east, Panchanagar VDC in the west, Dhurkot and Dumkibas VDC in the north and Jahada, Jamunia and Daunnedevi VDCs in the south.

\section{Adoption of beekeeping enterprise}

The survey findings revealed that socially mobilized group had higher rate of beekeeping enterprise adoption $(82.4 \%)$ as compared to non-mobilized group (56.0\%) (Table 2). This shows the adoption of beekeeping enterprise significantly higher $(66.7 \%)$ in the district. 
Table 1. Mean and rounded up scores assigned to each of the selected improved beekeeping practices

\begin{tabular}{|llccc|}
\hline SN & Selected beekeeping practices & $\begin{array}{c}\text { Mean score } \\
\bar{X})^{*}\end{array}$ & $\begin{array}{c}\text { Score } \\
\bar{X}) \times 5\end{array}$ & $\begin{array}{c}\text { Rounded } \\
\text { score }\end{array}$ \\
\hline 1. & Beekeeping occupation and type of hive products & 3.0 & 15.0 & 15 \\
2. & Honeybee races and management technology & 4.6 & 23.0 & 23 \\
3. & Seasonal management and routine inspection & 4.9 & 24.5 & 25 \\
4. & Colony union & 3.5 & 17.5 & 18 \\
5. & Colony division & 3.0 & 15.0 & 15 \\
6. & Artificial queen rearing & 3.0 & 15.0 & 15 \\
7. & Use of comb foundation & 4.4 & 22.0 & 22 \\
8. & Artificial feeding & 4.9 & 24.5 & 25 \\
9. & Foraging management and pollination & 3.9 & 19.5 & 20 \\
10. & Swarming and absconding control & 4.1 & 20.5 & 20 \\
11. & Robbing control & 3.1 & 15.5 & 24 \\
12. & Honeybee pest (mite) and predator management & 4.8 & 24.0 & 15 \\
13. & Disease management & 3.1 & 15.5 & 22 \\
14. & Honey harvesting and processing & 4.4 & 22.0 & \\
\hline
\end{tabular}

* Mean score calculated based on the 1 to 5 scores obtained for each beekeeping practice from 10 apiculturists

Table 2. Adoption of beekeeping enterprise by socially mobilized and non-mobilized farmers, Nawalparasi, 2003

\begin{tabular}{|lcccc|}
\hline VDCs & $\begin{array}{c}\text { Adopted1 } \\
(\mathbf{\%})\end{array}$ & $\begin{array}{c}\text { Non-adopted } \\
\mathbf{( \% )}\end{array}$ & $\begin{array}{c}\text { Total } \\
\mathbf{( \% )}\end{array}$ & $\chi^{2}-$ value \\
\hline Pragatinagar (Mobilized) & 14 & $3 \mathrm{a}$ & 17 & $7.118^{* *}$ \\
Makar (Non-mobilized) & $(82.4)$ & $(17.6)$ & $(100.0)$ & 0.360 \\
& 14 & 11 & 25 & $4.667^{*}$ \\
Total & $(56.0)$ & $(44.0)$ & 42 & $(100.0)$ \\
\end{tabular}

1 - includes 1 household in Pragatinagar and 4 households in Makar VDC adopted after training, a - includes two households whose beekeeping enterprises failed earlier but not adopted later, $*$ and $* *$ significant at $\mathrm{p}<0.05$ and $\mathrm{p}<0.01$, respectively

\section{Adoption of improved beekeeping technology}

Adoption of the improved beekeeping technology at farmers' level in mobilized VDC was higher $(80.6 \%)$ than that of non-mobilized VDC (68.4\%) (Table 3). Beekeeping enterprise was fully adopted with modern hive and crossbred honeybee (A. mellifera), seasonal management and routine inspection, use of comb foundation, artificial feeding, control of swarming and absconding, and modern method of honey harvesting with centrifugal honey extractor in both groups whereas identification of disease incidence and its control was minimum $(\approx 0)$ in Makar VDC although it was adopted by only 14.3\% of households in Pragatinagar VDC too. Other practices, such as honey processing, artificial queen rearing and seasonal migration were also adopted at minimum level. Average adoption of improved beekeeping technology in the district was $74.5 \%$.

\section{Extent of adoption}

Extent of adoption of improved technology was significantly higher $(80.6 \%)$ among the mobilized farmers as compared to the non-mobilized group (68.4\%) (Table 3). In general, 78.6\% of the farm households had higher extent of adoption of improved beekeeping technology in Nawalparasi district constituting $92.9 \%$ and 64.3\% among the beekeeping households of Pragatinagar and Makar VDC, respectively. While only $21.4 \%$ of households, on an average, had moderate extent of adoption of improved technology in the district including $7.1 \%$ and $35.7 \%$ of households, respectively, in mobilized and non-mobilized households (Table 4). 
Table 3. Adoption of each improved beekeeping practice by number of households $(n=14)$ and extent of adoption of improved beekeeping technology by number of introduced technology $(n=14)$, Nawalparasi, 2003

\begin{tabular}{|lccc|}
\hline VDCs & $\begin{array}{c}\text { Maximum } \\
\mathbf{( \% )}\end{array}$ & $\begin{array}{c}\text { Minimum } \\
(\mathbf{\%})\end{array}$ & Average \pm SEm \\
\hline $\begin{array}{l}\text { Adoption of technology1 (\%)** } \\
\text { Pragatinagar (Mobilized) }\end{array}$ & 14 & 2 & $11.3 \pm 1.07$ \\
Makar (Non-mobilized) & $(100.0)$ & $(14.3)$ & $(80.6)$ \\
Extent of adoption (\%)* & 14 & 0 & $9.6 \pm 1.37$ \\
Pragatinagar (Mobilized) & $(100.0)$ & $(00.0)$ & $(68.4)$ \\
Makar (Non-mobilized) & 14 & 7 & $(80.6)$ \\
& $(100.0)$ & $(50.0)$ & $9.6 \pm 0.63$ \\
\hline
\end{tabular}

1 - Adoption of technology out of 14 (total) households adopting beekeeping enterprise in each VDC, $*$ and $* *$, Significant at $\mathrm{p}<0.05$ and $\mathrm{p}<0.01$ probability levels

Table 4. Extent of improved beekeeping technology adoption by number of households, Nawalparasi, 2003

\begin{tabular}{|lccc|}
\hline Extent of adoption & $\begin{array}{c}\text { Pragatinagar VDC } \\
\text { (Mobilized) }\end{array}$ & $\begin{array}{c}\text { Makar VDC } \\
\text { (Non-mobilized) }\end{array}$ & Average \\
\hline Low & 0 & 0 & 0 \\
$(\leq 33.3 \%)$ & $(0.0)$ & $(0.0)$ & $(0.0)$ \\
Moderate & 1 & 5 & 3 \\
$(33.4-66.7 \%)$ & $(7.1)$ & $(35.7)$ & $(21.4)$ \\
High & 13 & $(64.3)$ & 11 \\
$(>66.7 \%)$ & $(92.9)$ & 14 & $(78.6)$ \\
Total & 14 & $(100.0)$ & 14 \\
\end{tabular}

Figures in the parenthesis indicate the percentage value

\section{Honey yield and income}

There was significantly higher average yield of honey per colony per annum in mobilized VDC $(25.6 \mathrm{~kg})$ than that of non-mobilized one (15.6 kg) (Table 5). The lower yield in the Makar VDC could be due to unavailability as well as inadequate honeybee flora throughout the year. Annual average yield, in general, was $20.6 \mathrm{~kg} /$ colony in the district. Although maximum honey yield was higher in organized group, minimum honey yield was equal in both the groups, and therefore, there existed to exploit higher potential of honey production among the non-mobilized households. Mobilized VDC with adoption of improved technology improved household income (NRs 25,657.14) than that of non-mobilized one (NRs 10,364.29) based on the values estimated on the local market during the study period.

\section{Gender involvement}

Among the selected households, the involvement of men and women as members in the Beekeeping Farmers' Groups was $68.2 \%$ and $31.8 \%$ in mobilized VDC whereas it was $64.3 \%$ and $35.7 \%$ in non-mobilized VDC, respectively (Table 6). In Pragatinagar, both men and women represented as members from the same households. While in Makar VDC only either men or women participated in the group. Although women members were low in group, they actively participated in beekeeping besides their household activities. In general, involvement of men was relatively higher both in Beekeeping Farmers' Group (66.7\%) and beekeeping activity $(82.1 \%)$. 
Table 5. Yield of honey per colony per annum and farm income through beekeeping enterprise at farmers' level, Nawalparasi, 2003

\begin{tabular}{|lccc|}
\hline VDCs & Maximum & Minimum & Average \pm SEm \\
\hline Honey yield (kg/colony/annum)** & & & $25.6 \pm 2.28$ \\
Pragatinagar (Mobilized) & 40.0 & 10.0 & $15.6 \pm 2.01$ \\
Makar (Non-mobilized) & 30.0 & 10.0 & \\
Farm income from beekeeping enterprise* (NRs.) & & & $25,657.14 \pm 6962.772$ \\
Pragatinagar (Mobilized) & & 1,200 & $10,364.29 \pm 3484.307$ \\
Makar (Non-mobilized) & 75,000 & 2,000 & \\
\hline
\end{tabular}

* and **, Significant at $\mathrm{p}<0.05$ and $\mathrm{p}<0.01$ probability levels, 1 - Values estimated based on local price, 2003

Table 6. Gender involvement in Beekeeping Farmers' Groups (no. of group members), Nawalparasi, 2003

\begin{tabular}{|c|c|c|c|}
\hline VDCs & $\begin{array}{c}\text { Men } \\
(\%)\end{array}$ & $\begin{array}{c}\text { Women } \\
(\%)\end{array}$ & $\begin{array}{c}\text { Total } \\
(\%)\end{array}$ \\
\hline Pragatinagar (Mobilized) & $\begin{array}{c}15 \\
(68.2)\end{array}$ & $\begin{array}{c}7 \\
(31.8)\end{array}$ & $\begin{array}{c}22 \\
(100.0)\end{array}$ \\
\hline Makar (Non-mobilized) & $\begin{array}{c}9 \\
(64.3)\end{array}$ & $\begin{array}{c}5 \\
(35.7)\end{array}$ & $\begin{array}{c}14 \\
(100.0)\end{array}$ \\
\hline Total & $\begin{array}{c}24 \\
(66.7)\end{array}$ & $\begin{array}{c}12 \\
(33.3)\end{array}$ & $\begin{array}{c}36 \\
(100.0)\end{array}$ \\
\hline
\end{tabular}

\section{Extent of technology adoption}

Extent of improved technology adoption was much higher (83.1\%) in those households involving both men and women in beekeeping activity. Adoption of improved technology was more $(78.6 \%)$ in the only men involved beekeeping activity whereas it was less $(48.6 \%)$ in the only women involved beekeeping activity (Table 7).

Table 7. Gender involvement in beekeeping by number of households and extent of improved technology adoption, Nawalparasi, 2003

\begin{tabular}{|c|c|c|c|c|}
\hline VDCs & $\begin{array}{c}\text { Men } \\
(\%)\end{array}$ & $\begin{array}{c}\text { Women } \\
(\%)\end{array}$ & $\begin{array}{c}\text { Both } \\
(\%)\end{array}$ & $\begin{array}{l}\text { Total } \\
(\%)\end{array}$ \\
\hline \multicolumn{5}{|c|}{ Gender involvement in beekeeping activity (\%) } \\
\hline Pragatinagar & 6 & 1 & 7 & 14 \\
\hline (Mobilized) & $(42.9)$ & $(7.1)$ & $(50.0)$ & $(100.0)$ \\
\hline Makar & 6 & 4 & 4 & 14 \\
\hline (Non-mobilized) & $(42.9)$ & $(28.6)$ & $(28.6)$ & $(100.0)$ \\
\hline \multicolumn{5}{|c|}{ Extent of adoption $(\%)$} \\
\hline Pragatinagar & 11.5 & 7 & 11.7 & 11.3 \\
\hline (Mobilized) & $(82.1)$ & $(50.0)$ & $(83.7)$ & $(80.6)$ \\
\hline Makar & 10.2 & 6.8 & 11.5 & 9.6 \\
\hline (Non-mobilized) & $(72.6)$ & $(48.2)$ & $(82.1)$ & $(68.4)$ \\
\hline
\end{tabular}

\section{Correlation study}

The estimates of correlation coefficients showed the significant linear relationship between number of honeybee colonies, extent of improved technology adoption, honey yield and farm income from beekeeping but the linear correlation of number of family members involved in beekeeping activity to those other parameters was not significantly different in mobilized VDC (Pragatinagar) while it was significantly different in nonmobilized VDC (Makar) (Table 8). This non-significant relationship but higher degree of technology adoption is due to the involvement of less but skilled members of the households in the mobilized group. 
Table 8. Linear correlation coefficient between different parameters of beekeeping enterprise at farmers' level $(n=14)$, Nawalparasi, 2003

\begin{tabular}{|llcccc|}
\hline VDCs & Parameters & No. of colonies & Extent of adoption & Honey yield & Farm income \\
\hline Pragatinagar & No. of member involved & $0.240^{\mathrm{ns}}$ & $0.479^{\mathrm{ns}}$ & $0.229^{\mathrm{ns}}$ & $0.084^{\mathrm{ns}}$ \\
(Mobilized) & No. of colonies & & $0.730^{* *}$ & $0.763^{* *}$ & $0.874^{* *}$ \\
& Extent of adoption & & & $0.638^{*}$ & $0.667^{* *}$ \\
& Honey yield & & & $0.672^{* *}$ \\
Makar & No. of member involved & $0.857^{* *}$ & $0.721^{* *}$ & $0.755^{* *}$ & $0.824^{* *}$ \\
(Non-mobilized) & No. of colonies & & $0.802^{* *}$ & $0.672^{* *}$ & $0.988^{* *}$ \\
& Extent of adoption & & & $0.736^{* *}$ & $0.821^{* *}$ \\
& Honey yield & & & $0.699^{* *}$ \\
\hline
\end{tabular}

* and ${ }^{* *}$, significant at $\mathrm{p}<0.05$ and $\mathrm{p}<0.01$, respectively

\section{Adoption index}

Mobilized VDC practiced beekeeping technology with the higher index of adoption $(77.44 \%)$ which was 1.29 times higher as compared to non-mobilized VDC (Table 9). Adoption index varied greatly in non-mobilized (Makar) VDC (Std = 32.52) while it was less in mobilized (Pragatinagar) VDC (Std = 23.94).

Table 9. Adoption index of beekeeping farmers' households by socially mobilized and non-mobilized farmers, Nawalparasi, 2003

\begin{tabular}{|c|c|c|c|}
\hline VDCs & $\begin{array}{c}\text { Maximum } \\
(\%)\end{array}$ & $\begin{array}{c}\text { Minimum } \\
(\%)\end{array}$ & Average \pm SEm \\
\hline Pragatinagar (Mobilized) & $\begin{array}{c}233 \\
(85.03)\end{array}$ & $\begin{array}{c}146 \\
(53.28)\end{array}$ & $\begin{array}{c}206.7 \pm 6.39 \\
(77.44)\end{array}$ \\
\hline Makar (Non-mobilized) & $\begin{array}{c}218 \\
(79.50)\end{array}$ & $\begin{array}{c}115 \\
(41.97)\end{array}$ & $\begin{array}{c}160.9 \pm 8.6 \\
(58.73)\end{array}$ \\
\hline
\end{tabular}

The perception of farmers towards the improved technology was different between the mobilized and non-mobilized groups. The rate of adoption of beekeeping technology was higher (82.4\%) in socially mobilized groups. This could be due to creativity of farmers through mobilization activities. Jones (2000) reported that knowledge can be improved by education and sharing of information. Srivastava and Tripathi (1983) reported better scientific adoption of beekeeping after training. The extent of adoption in mobilized VDC was higher with higher adoption index, whereas it was lower in non-mobilized VDC.

After training and mobilization of people in modern beekeeping in Pakistan, adoption of A. mellifera, an exotic cross breed, increased honey production from average yield of $4 \mathrm{~kg} /$ colony/annum of native honeybee, A. cerana in 1982 to about $21 \mathrm{~kg} /$ colony/annum of $A$. mellifera in 1996 with the overall production from $250 \mathrm{mt}$ in 1982 to more than $1800 \mathrm{mt}$ in 1997 (Muzaffar, 2000). This fact justifies significantly higher average yield of honey per colony per annum in mobilized VDC $(25.6 \mathrm{~kg})$ as compared to non-mobilized VDC (15.6 kg) in farm situation. Mobilized households improved their income through beekeeping (NRs 25,657.14) than that on nonmobilized one (NRs 10,364.29). Annual yield of honey (20.6 kg/colony) averaged over these two VDCs exceeds district average of $16.67 \mathrm{~kg}$ per colony, whereas national average has been estimated only $4.15 \mathrm{~kg}$ per colony per annum (HMG/N, 2002). Improvement in family earnings from beekeeping has been reported (Maskey 1992; Muzaffar, 1992). Crane (1992) reported sufficient or ample income from beekeeping in America and Europe or Mediterranean region where beekeepers owned a car or truck or even a small plane to monitor their apiaries. In Africa and Asia, beekeepers are rich with modern hives and modern beekeeping.

Though women can handle bees successfully and surpass men in proficiency in those parts of the business which require delicacy of touch and minute attention (Phillips, 2001), the involvement of women in Beekeeping Farmers' Group as well as beekeeping activity was lower. Kumar (2000) and Saville (2000) reported that the causes of limited involvement of women were gender imbalance, lack of scientific knowledge and awareness of beekeeping, considering beekeeping as men's activity, and women's duties in home or unavailability of time in beekeeping. 


\section{REFERENCES CITED}

APROSC and JMA. 1995. Nepal agriculture perspective plan (APP). Agricultural Projects Services Centre, Kathmandu and John Mellor Associates, Inc., Washington D. C. 337 p.

Baptist, B. A. and R. K. W. Punchihewa. 1983. A preliminary analysis of the principal factors which will affect apiary honey production in Sri Lanka. In: K. N. Mehrotra, M. G. Jotwani, T. P. Sriharan, B. Subrahmanyam, P. J. Rao, D. S. Bisht and M. Naim (eds.) Second International Conference on Apiculture in Tropical Climate. Indian Agricultural Research Institute, New Delhi, India. pp. 87-99.

Crane, E. 1992. Beekeeping in mountain life-support systems. In: L. R. Verma (ed.) Honeybees in Mountain Agriculture. Proceedings of International Expert Meeting on Beekeeping Development in the Hindu Kush-Himalayan Region, Kathmandu, Nepal, June 21-23, 1989. Oxford and IBH Publishing Co. Pvt. Ltd., New Delhi, India. pp. 17-27.

DADO. 2001. Annual agriculture development program and progress highlight. District Agriculture Development Office, Nawalparasi, Nepal. 114 p.

Dangol, B. B. S. 1979. Factors affecting adoption of improved agricultural practices of paddy cultivation in Chitwan district of Nepal. M. Sc., Thesis. University of Udaipur, Jobner, India.

Devkota, C. K. 1987. Adoption of recommended practices of rice in the hill district, Syangja, Nepal. M. Sc., Thesis. University of the Philippines, Los Banos, Philippines.

Entomology Division. 1998. Annual technical report (1997-1998). Nepal Agriculture Research Council, Khumaltar, Lalitpur, Nepal. 59 p.

Entomology Division. 1999. Annual technical report (1998-1999). Nepal Agriculture Research Council, Khumaltar, Lalitpur, Nepal. 64 p.

HMG/N. 2002. Annual progress and statistical book (2001 - 2002) (in Nepali). Bee Development Section, Godawari, Nepal. 47 p.

ICIMOD. 1999. Indigenous honeybees of the himalayas: A community based approach to conserving biodiversity and increasing farm productivity. ICIMOD/AUSTRO Project Programme, International Centre for Integrated Mountain Development, Kathmandu, Nepal.

Jodha, N. S. 1992. Mountain perspective and beekeeping. In: L. R. Verma (ed.) Honeybees in Mountain Agriculture. Proceedings of International Expert Meeting on Beekeeping Development in the Hindu Kush-Himalayan Region, Kathmandu, Nepal, June 21-23, 1989. Oxford and IBH Publishing Co. Pvt. Ltd., New Delhi, India. pp. 29-33.

Jones, R. 2000. IGRA's role in educating people about beekeeping. In: M. Matsuka, L. R. Verma, S. Wongsiri, K. K. Shrestha and U. Partap (eds.) Asian Bees and Beekeeping: Progress of Research and Development. Proceedings of Fourth Asian Apicultural Association International Conference, Kathmandu, March 2328, 1998. Oxford and IBH Publishing Co. Pvt. Ltd., New Delhi, India. pp. 240-241.

Kafle, G. P. 1992. Salient features of beekeeping in Nepal. In: L. R. Verma (ed.) Honeybees in Mountain Agriculture. Proceedings of International Expert Meeting on Beekeeping Development in the Hindu Kush-Himalayan Region, Kathmandu, Nepal, June 21-23, 1989. Oxford and IBH Publishing Co. Pvt. Ltd., New Delhi, India. pp. 155-162.

Koirala, G. P. and G. B. Thapa. 1997. Food security challenges: Where does Nepal stand? HMG/N, MOA/ Winrock International, Kathmandu, Nepal. 41 p.

Kumar, N. R. 2000. Beekeeping: Self-employment opportunity for mountain women. In: M. Matsuka, L. R. Verma, S. Wongsiri, K. K. Shrestha and U. Partap (eds.) Asian Bees and Beekeeping: Progress of Research and Development. Proceedings of Fourth Asian Apicultural Association International Conference, Kathmandu, March 23-28, 1998. Oxford and IBH Publishing Co. Pvt. Ltd., New Delhi, India. pp. 245-247.

Maskey, M. 1992. Mountain women and beekeeping in Nepal. In: L. R. Verma (ed.) Honeybees in Mountain Agriculture. Proceedings of International Expert Meeting on Beekeeping Development in the Hindu Kush-Himalayan Region, Kathmandu, Nepal, June 21-23, 1989. Oxford and IBH Publishing Co. Pvt. Ltd., New Delhi, India. pp. 120-123.

Muzaffar, N. 1992. Beekeeping - An income-generating cottage industry for rural women in Pakistan. In: L. R. Verma (ed.) Honeybees in Mountain Agriculture. Proceedings of International Expert Meeting on 
Beekeeping Development in the Hindu Kush-Himalayan Region, Kathmandu, Nepal, June 21-23, 1989. Oxford and IBH Publishing Co. Pvt. Ltd., New Delhi, India. pp. 113-117.

Muzaffar, N. 2000. Beekeeping in Pakistan: Present status and economics (Box news). In: M. Matsuka, L. R. Verma, S. Wongsiri, K. K. Shrestha and U. Partap (eds.) Asian Bees and Beekeeping: Progress of Research and Development. Proceedings of Fourth Asian Apicultural Association International Conference, Kathmandu, March 23-28, 1998. Oxford and IBH Publishing Co. Pvt. Ltd., New Delhi, India. pp. 225.

Pant, N. C. 1983. Beekeeping as a rural industry in the tropics with special reference to India. In: K. N. Mehrotra, M. G. Jotwani, T. P. Sriharan, B. Subrahmanyam, P. J. Rao, D. S. Bisht and M. Naim (eds.) Second International Conference on Apiculture in Tropical Climate. Indian Agricultural Research Institute, New Delhi, India. pp. $75-81$.

Phillips, E. F. 2001. Beekeeping. Agrobios, Jodhpur, India. 490 p.

Pretty, J. N. 1996. Regenerating agriculture: Policies and practice for sustainability and self-reliance. Vikas Publishing House Pvt. Ltd., New Delhi, India. 320 p.

Saville, N. M. 2000. Farmer participatory extension in Jumla, western Nepal. In: M. Matsuka, L. R. Verma, S. Wongsiri, K. K. Shrestha and U. Partap (eds.) Asian Bees and Beekeeping: Progress of Research and Development. Proceedings of Fourth Asian Apicultural Association International Conference, Kathmandu, March 23-28, 1998. Oxford and IBH Publishing Co. Pvt. Ltd., New Delhi, India. pp. 230-236.

Shakya, D. B. 2003. Nepalese honey market: Private sector perspectives. Paper presented to Norwegian Expert Team. Agro Enterprise Centre (FNCCI), Kathmandu, Nepal.

Shivakoti, G. P. and S. Bista. 2000. Major constraints in the performance of Apis mellifera and Apis cerana under Khumaltar conditions. In: M. Matsuka, L. R. Verma, S. Wongsiri, K. K. Shrestha and U. Partap (eds.) Asian Bees and Beekeeping: Progress of Research and Development. Proceedings of Fourth Asian Apicultural Association International Conference, Kathmandu, March 23-28, 1998. Oxford and IBH Publishing Co. Pvt. Ltd., New Delhi, India. pp. 29-32.

Shrestha, K. K. and L. R. Verma. 1992. Beekeeping research and training in hindu kush-himalayan region: Future perspectives. In: L. R. Verma (ed.) Honeybees in Mountain Agriculture. Proceedings of International Expert Meeting on Beekeeping Development in the Hindu Kush-Himalayan Region, Kathmandu, Nepal, June 21-23, 1989. Oxford and IBH Publishing Co. Pvt. Ltd., New Delhi, India. pp. 251-257.

Shrestha, N. C. T. D. 2000. Beekeeping status and role of bee development section for promoting modern beekeeping in Nepal. Paper presented at National Plant Protection Workshop, June 13-15, 2000, Kathmandu. Plant Protection Division, Hariharbhawan, Lalitpur, Nepal. pp. 61-71.

Srivastava, D. C. and R. L. Tripathi. 1983. Propects of apiculture in tribal areas of Chotanagpur. In: K. N. Mehrotra, M. G. Jotwani (eds.). pp. 227-232. 